\title{
Study of sex ratio in progeny of a complex Oreochromis hybrid, the Florida red tilapia
}

\author{
Damien Desprez ${ }^{\mathrm{a}, \mathrm{b}, \mathrm{c}, *}$, Cédric Briand ${ }^{\mathrm{b}}$, Marie Claude Hoareau ${ }^{\mathrm{a}}$, Charles Mélard ${ }^{\mathrm{c}}$, \\ Pierre Bosc ${ }^{\text {a }}$, Jean François Baroiller ${ }^{\text {b,d }}$ \\ ${ }^{\mathrm{a}}$ ARDA, Freshwater Aquaculture Centre, BP 16, ZI Les Sables, 97427 Etang Salé, Reunion Island, France \\ ${ }^{\mathrm{b}}$ CIRAD EMVT, Aquaculture Research Unit, BP 5095, 34033 Montpellier cedex 1, France \\ ${ }^{\mathrm{c}}$ University of Liege, CEFRA, 10 chemin de la Justice, 4500 Tihange, Belgium \\ ${ }^{\mathrm{d}}$ INRA, Laboratory of Fish Physiology, Avenue du Général Leclerc, 35042 Rennes cedex, France
}

Received 1 December 2004; received in revised form 13 June 2005; accepted 24 June 2005

\begin{abstract}
This paper reports a study on the progeny sex-ratio distribution in the Florida red tilapia. This hybrid originated as a cross between $O$. mossambicus male and $O$. urolepis hornorum female, which was then crossed with $O$. niloticus and $O$. aureus in order to improve its growth rate and its resistance to low temperature. We have studied the sex-ratio of 111 progenies from 46 females and 12 males, where the male percentage varied between $5 \%$ to $89 \%$. The analysis of distribution showed three groups characterised by a mean male percentage of $26.7 \pm 9.8 ; 50.0 \pm 8.9$ and $70.3 \pm 5.5 \%$. The stability of sex ratios in repeated single pair matings and the parental influence on progeny sex ratios obtained are in agreement with a polygenic basis of sex determination in this complex hybrid.
\end{abstract}

(c) 2005 Elsevier B.V. All rights reserved.

Keywords: Sex-ratio; Sex determination; Oreochromis; Tilapia; Florida red tilapia

\section{Introduction}

The model of sex determination has been intensively studied in the genus Oreochromis, where both male homogamety (ZZ/WZ) and female homogamety (XX/ $\mathrm{XY}$ ) have been proposed, based on experimental sex-

\footnotetext{
* Corresponding author. ARDA, Freshwater Aquaculture Centre, BP 16, ZI Les sables, 97427 Etang Salè, Reunion Island, France. Tel.: +33262 2622650 82; fax: +33262 262265001 .

E-mail address: desprez.arda@wanadoo.fr (D. Desprez).
}

ratios from inter- and intra-specific crosses, involving normal or sex-reversed parents, and also from chromosome-set manipulations (triploidisation and gynogenesis) (Jalabert et al., 1971; Mair et al., 1991a,b; Trombka and Avtalion, 1993; Müller-Belecke and HörstgenSchwark, 1995). Observation of significant deviations from predicted sex ratios suggests the influence of additional factor(s) (environmental or genetic) other than sex chromosomes on the sex determination in this genus (Avtalion and Hammerman, 1978; Majumdar and McAndrew, 1983; Mair et al., 1991a,b; Wohl- 
farth and Wedekind, 1991; Baroiller and D'Cotta, 2001; Desprez et al., 2003a). The main interest in the model of sex determination in tilapia is motivated by the practical and commercial implications in the production of monosex male populations for aquaculture. Monosex male populations, usually preferred to optimise the production system (males grow faster than females; decreased reproduction; reduction of sexual/ territorial behaviour; achievement of higher average growth rate), are generally produced on a large scale by hormonal sex inversion or by genetic approaches (interspecific hybridisation; YY super male or ZZ pseudofemale technology, respectively in $O$. niloticus and O. aureus) (Guerrero and Guerrero, 1988; Wohlfarth, 1994; Mair et al., 1997; Desprez et al., 2003a).

Apart from manual sexing, sex reversal with androgen is the only process used to produce populations of high male percentage in Florida red tilapia (Desprez et al., 2003b). This hybrid, supposedly resulting from hybridisation of four species (O. niloticus and $O$. mossambicus with XX/XY model; O. hornorum urolepis and O. aureus with ZZ/ZW model), is one of the most commercially important tilapia strains, notably in Latin America, Asia, Caribbean and in Reunion Island. Studies on interspecific crosses suggested that a complex model or a polygenic system of sex determination exists in hybrids (Pruginin et al., 1975; Avtalion and Hammerman, 1978; Majumdar and McAndrew, 1983). However, results on hybridisation and sex determination in hybrids were restricted to the $F_{1}$ to $F_{3}$ generations (Chen, 1969; Jalabert et al., 1971). The sex ratio distribution in a complex hybrid after many generations since the 1970s is little known. The purpose of this paper was therefore to investigate the progeny sexratio in Florida red tilapia. Investigations of the possible model of sex determination in this hybrid are a preliminary stage, before a possible genetic approach for the production of monosex male population in red tilapia hybrids.

\section{Materials and methods}

\subsection{Origin of fish}

This study was carried out at the Freshwater Aquaculture Centre (A.R.D.A.) in Reunion Island (Indian Ocean). The experimental fish were a commercial red tilapia strain known as Florida red tilapia. The Florida red tilapia originated from a cross between a red mutant male of $O$. mossambicus and a female of $O$. urolepis hornorum (Behrends et al., 1982). In order to improve its growth rate and its resistance to low temperature, this hybrid was crossed with $O$. niloticus and O. aureus (Behrends and Smitherman, 1984). Two commercial Florida red tilapia strains, imported from Martinique (1990) and Jamaica (1991), were mixed in 1991/1992 to give the Florida red tilapia strain, used at present in Reunion Island. Florida red tilapia males and females tested in present study were taken from the broodstock of the Freshwater Aquaculture Centre.

\subsection{Progeny testing}

Florida red tilapia males and females were maintained in a series of 400-1 thermo-regulated aquaria $\left(27 \pm 1^{\circ} \mathrm{C}\right)$ in a recirculating system (one male and 34 females per aquarium). All tested males and females were individually tagged with passive integrated transponder tags (PIT tag system/Destron Fearing Corporation, USA). The reproductive status was checked twice a day by detection of female mouthbrooding behaviour. Mouthbrooding females were isolated in their respective aquaria with a movable partition. Fry were removed from the mouth of female 9-10 days after spawning. The mean number of fry reared per progeny was $369 \pm 278$, ranging from 135 to 1694 . Each progeny was identified by male and female tag numbers and was reared in a 100-1 tank within a recirculating system. The minimum and maximum temperatures for these experiments were 26.8 and $31.2{ }^{\circ} \mathrm{C}$, respectively. After a period of 60 to 90 days or on attaining an average weight of $>3 \mathrm{~g}$, a sample of 100 to 200 fish from each progeny group was sexed by the aceto-carmine squash method (Guerrero and Shelton, 1974). At this stage of development, oocytes are easily identifiable in their auxocytosis or previtellogenesis stages and a typical lobular configuration is observed in the testes. The sex ratios of progenies were compared using a $2 \times 2$ contingency $\chi^{2}$ test.

\section{Results}

Eighty four single pair-mating, involving 12 males and 46 females of broodstock, were produced in the 
Table 1

Summary of sex ratios from single-pair mating of Florida red tilapia

\begin{tabular}{lc}
\hline & All crosses \\
\hline Male broodstock & 12 \\
Female broodstock & 46 \\
Progeny groups & 111 \\
Fry sexed & 20,577 \\
Fry survival rate (\%) & 54.8 \\
Minimum \% male & 5 \\
Maximum \% male & 89 \\
Mean \% male & 51.3 \\
\hline
\end{tabular}

present study: twenty-three of these crosses had two replicates and two had three replicates. Thus a total of 111 progenies were reared with a mean survival rate of 54.8, ranging from 21.8 to $96.4 \%$ (Table 1).

Data from repeated crosses of single pair-mating that were found to be homogenous $\left(\chi^{2}\right.$ test), were pooled (Fig. 1 and Table 2). There was a large variability in sex ratios of Florida red tilapia progeny groups. The male percentage ranged from $5.0 \%$ to $89.0 \%$ with a mean of $51.3 \%$ (Table 1 ).

Fig. 1 shows the distribution of sex ratio among progeny groups (sexed sample size $\geq 100$ ). Analysis of this distribution into Gaussian components (Bhat-
Table 2

Progeny sex-ratios $(\hat{\delta}:$ ) from repeated pair mating (two or three replicates) in Florida red tilapia

\begin{tabular}{|c|c|c|c|c|c|c|}
\hline $\begin{array}{l}\text { Cross } \\
(\hat{0} \times \uparrow) \\
\end{array}$ & $\begin{array}{l}1 \\
\% \text { male }\end{array}$ & $\begin{array}{l}2 \\
\% \text { male }\end{array}$ & $\begin{array}{l}3 \\
\% \text { male }\end{array}$ & $\begin{array}{l}\text { Cross } \\
(\widehat{\delta} \times \uparrow)\end{array}$ & $\begin{array}{l}1 \\
\% \text { male }\end{array}$ & $\begin{array}{l}2 \\
\% \text { male }\end{array}$ \\
\hline $240 \times 245^{*}$ & 32 & 46 & 39 & $212 \times 119$ & 59 & 61 \\
\hline $023 \times 87 d$ & 38 & 32 & 26 & $239 \times 119$ & 40 & 53 \\
\hline $023 \times 41 \mathrm{c}$ & 35 & 48 & & $225 \times 201$ & 19 & 18 \\
\hline $07 d \times 512$ & 68 & 61 & & $240 \times 205$ & 47 & 41 \\
\hline $068 \times 614$ & 54 & 60 & & $240 \times 220$ & 53 & 51 \\
\hline B $47 \times 642$ & 61 & 56 & & $212 \times 222$ & 50 & 61 \\
\hline $07 \mathrm{~d} \times 642 *$ & 48 & 33 & & $213 \times 222$ & 55 & 45 \\
\hline $068 \times 818$ & 47 & 50 & & $221 \times 233$ & 62 & 66 \\
\hline $023 \times a 7 c$ & 43 & 38 & & $212 \times 248$ & 60 & 48 \\
\hline $\mathrm{B} 47 \times \mathrm{a} 7 \mathrm{c} *$ & 68 & 48 & & $213 \times 248$ & 46 & 50 \\
\hline $64 f \times b 2 c$ & 53 & 59 & & $221 \times 266$ & 52 & 64 \\
\hline $71 \mathrm{e} \times \mathrm{e} 1 \mathrm{~b}^{*}$ & 46 & 61 & & $239 \times 860$ & 63 & 65 \\
\hline $07 \mathrm{~d} \times \mathrm{flf}$ & 53 & 53 & & & & \\
\hline
\end{tabular}

* Sex-ratio significantly different $\left(\chi^{2}\right.$ test; $\left.d f=1 ; P<0.05\right)$ from one or other results in successive crosses.

tacharya, 1967) showed three groups (Fig. 1). A group was characterised by a mean male percentage \pm standard deviation, the minimum and maximum limits and the percentage of single pair-mating included in the group. The main group (58\% of the single pair-matings) had a mean male percentage of

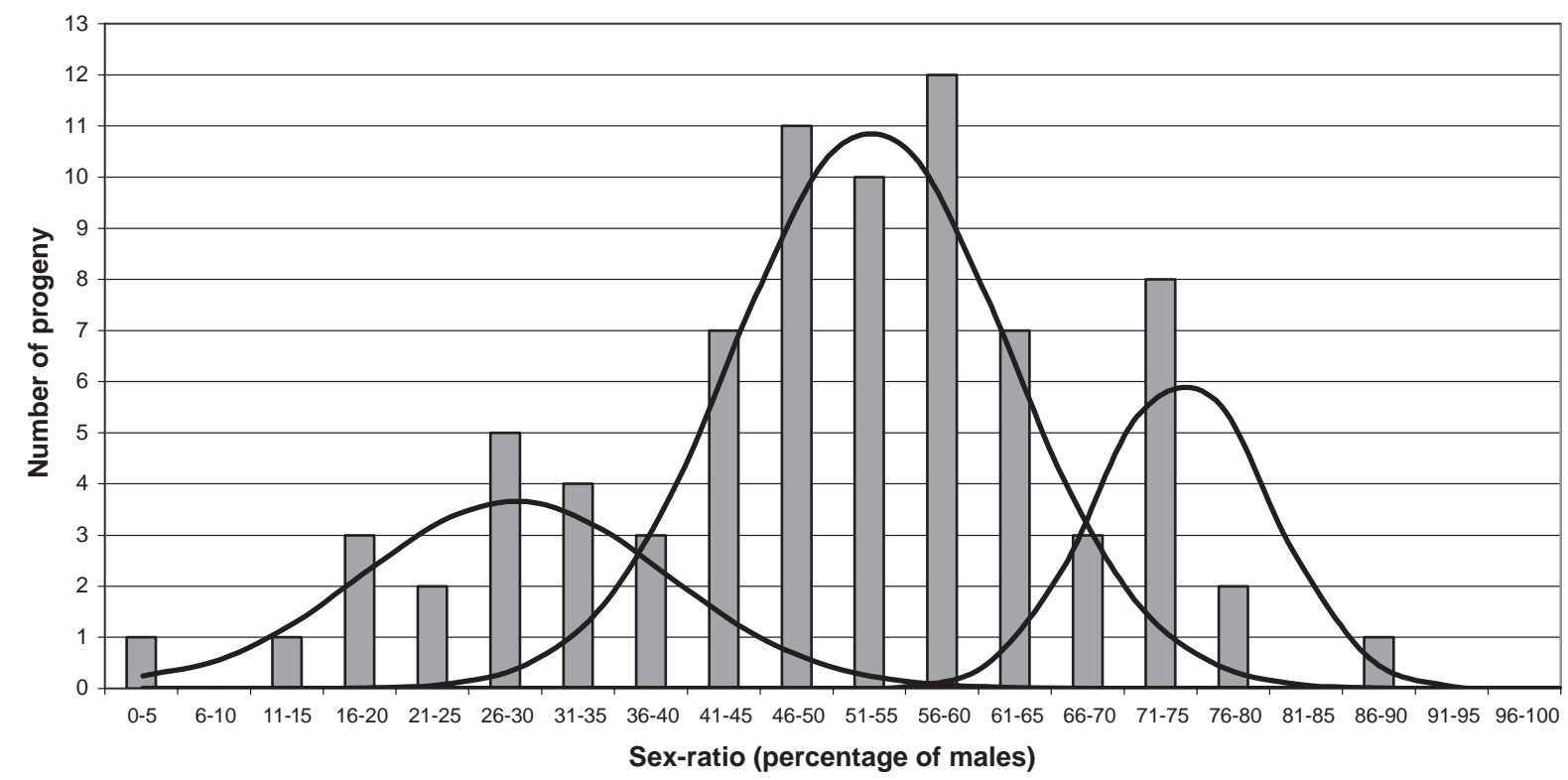

Fig. 1. Sex-ratio distribution of progeny groups from single-pair mating of Florida red tilapia as determined using the Gaussian distribution analysis of Bhattachariya (1967). 
$50.0 \pm 8.9 \%$. The minimum and the maximum limits of this group were $41.1 \%$ and $58.9 \%$ of male, respectively. A second group (22\% of single pair-matings) had a lower male percentage $(26.7 \pm 9.8 \%)$ with a minimum and a maximum of $16.9 \%$ and $36.6 \%$, respectively. The last group had a mean male percentage of $70.3 \pm 5.5 \%$, contained between $64.8 \%$ and $75.8 \%$. Three single pair-matings, producing respectively $5 \%, 11 \%$ and $89 \%$ male, were not included in the three groups given by the analysis of the distribution into Gaussian components (Bhattacharya, 1967) (Fig. 1).

Progeny sex-ratios from repeated pair-mating ( $n=25$ pair-matings) were not significantly different in the successive crossings, except for four pair-matings presenting heterogeneous results (Table 2). The two crosses of male " $71 \mathrm{e}$ " $\times$ female "elb" produced sex ratios that were not significantly different from $1: 1$. In contrast, among the crosses between male "240" $\times$ " 245 ", two sex ratios were not significantly different from $1: 1 \quad\left(\chi^{2}=0.32\right.$ and $2.45 ; \quad d f=1$; $P<0.05)$ and the other one was not significantly different from $1: 3\left(\chi^{2}=1.20 ; d f=1 ; P<0.05\right)$. Similar results were observed with the pair-mating "07d" $\times$ "642" and "b47" $\times$ "a7c" (Table 2). The difference in survival rate in successive crossings of a pairmating ranged from $0.7 \%$ ("212" $\times$ " 119 " with a survival rate of $21.8 \%$ and $22.5 \%$, respectively) to $51.9 \%$ ("213" $\times$ " 222 " with $19.9 \%$ and $71.8 \%$ ). In the four pair-matings, presenting significantly heterogeneous sex-ratios, the variation of the survival rate in the successive crossings was higher in cross " $71 \mathrm{e}$ " $\times$ " $\mathrm{e} 1 \mathrm{~b}$ " $"(25.9 \%$ and $69.6 \%)$ than in the three others $(48.5$ to $68.5 \%$ in cross " 240 " $\times$ " 245 "; $74.1 \%$ and $88.4 \%$ in cross " $07 \mathrm{~d} " \times$ " $642 " ; 81.7$ and $92.3 \%$ in cross "B47" $\times$ “a7c").

Table 3 shows the sex ratio resulting of crosses of 3 males with 16 females. The sex ratios obtained from crosses of male " 225 " with seven different females were skewed towards female $(72 \%$ to $95 \%$ of females). On the other hand, crosses of male " 213 " with four females gave balanced sex ratios ( $44 \%$ to $51 \%$ of males). In contrast, the crosses of male " 212 " with nine different females produced balanced sex ratios or skewed towards male sex ratios (Table 3 ). Crossing females " 222 " and " 248 ", the percentage of males in progeny involving males " 212 " and " 213 " ( $48 \%$ to $56 \%$ ) was significantly higher than with male
Table 3

Sex-ratios $(\hat{0}:$ : $)$ from crosses of three males and sixteen females in Florida red tilapia

\begin{tabular}{|c|c|c|c|}
\hline \multirow[t]{2}{*}{ Female (no.) } & \multicolumn{3}{|c|}{ Male (no.) } \\
\hline & 212 & $213^{\mathrm{a}}$ & 225 \\
\hline 119 & $60: 40$ & & \\
\hline 201 & & & $16: 84$ \\
\hline 209 & & $44: 56$ & \\
\hline 211 & $72: 28$ & & \\
\hline 220 & & & $28: 72$ \\
\hline $222 *$ & $56: 44$ & $50: 50$ & $11: 89$ \\
\hline 227 & & & $18: 82$ \\
\hline 232 & $46: 54$ & & \\
\hline 234 & $61: 39$ & & \\
\hline 236 & & & $16: 84$ \\
\hline 241 & & $51: 49$ & \\
\hline 242 & & & $24: 76$ \\
\hline 243 & $71: 29$ & & \\
\hline $248^{*}$ & $54: 46$ & $48: 52$ & $5: 95$ \\
\hline 859 & $68: 32$ & & \\
\hline 860 & $63: 37$ & & \\
\hline
\end{tabular}

${ }^{\text {a }}$ Sex-ratio not significantly different $\left(\chi^{2}\right.$ test; $\chi^{2}<2.00 ; d f=1$; $P<0.05)$ from one or other results in successive crosses.

* Sex-ratio significantly different $\left(\chi^{2}\right.$ test; $\chi^{2}>35.90 ; d f=1$; $P<0.05)$ from result in cross of male " 225 ".

" 225 " (5 and 11\%) ( $\chi^{2}$ test; $\left.\chi^{2}>35.9 ; d f=1 ; P>0.05\right)$ (Table 3).

\section{Discussion}

The frequency distribution of sex ratios, with three peaks at $27 \%, 50 \%$ and $70 \%$ of males suggests a polygenic sex determination model in the hybrid Florida red tilapia. The stability of sex ratio in most repeated crosses and the observed parental influence on progeny sex ratios are in agreement with a polygenic basis of sex determination in this complex Florida red tilapia hybrid. The significant differences, observed between the sex ratio in the few repeated crosses ("240" × "245"; "07d" × "642"; "B47” × "a7c"; "71e" $\times$ "e1b") are unexplained. Differential survival of the sexes is not sufficient to explain these variations: the results in the present study show that the progeny sex ratios in the successive crossings from the repeated pair-matings is not influenced by the survival rate. The effect of rearing temperature on sex determination is well known in Oreochromis niloticus (Baroiller et al., 1995). In the present study, it is unlikely that temperature was involved because the 
rearing temperature $\left(26.8\right.$ to $31.2{ }^{\circ} \mathrm{C}$ ) of Florida red tilapia progenies was below the minimum level (34 ${ }^{\circ} \mathrm{C}$ ) for temperature influence determined by Baroiller et al. (1995) in O. niloticus. However, other environmental factors ( $\mathrm{pH}$, day length....) could influence the sex determination and could induce slight variations of sex ratio, explaining the differences in repeated crossings in Florida red tilapia.

To explain unpredicted results in Oreochromis, which are not consistent with a monofactorial sex chromosomes model, a more complex system was proposed by adding a further genetic sex determining/regulating locus, the autosomal recessive gene $(\mathrm{F}, \mathrm{f})$ to the major "sex chromosomes" (Wohlfarth and Wedekind, 1991; Mair et al., 1991a,b; Trombka and Avtalion, 1993; Desprez et al., 2003a). Crossingover and recombination of sex determining genes could also account for these unpredicted sex-ratios (Mair et al., 1991a,b; Müller-Belecke and HörstgenSchwark, 1995). The complexity of sex determination model in the pure species of Oreochromis is encountered in its hybrids involving species with two opposing "sex chromosomes" models (XX/XY in $O$. niloticus and $O$. mossambicus and $\mathrm{WZ} / \mathrm{ZZ}$ in $O$. aureus and $O$. urolepis hornorum). The four "sex chromosomes" (W, X, Y, Z) model also failed to explain all sex ratio results obtained in hybrids (Chen, 1969; Jalabert et al., 1971; Pruginin et al., 1975) and Avtalion and Hammerman (1978) proposed an autosomal theory, assuming that sex is determined by "sex chromosomes" and a pair of autosomes. Stating that $\mathrm{Z}$ and $\mathrm{Y}$ chromosomes seem to be identical, the autosomal theory would be based on three gonosomes (X, Y, W) and each genotype would have a complement of two gonosomes (XX, XY, XW, WY, WW or YY) and a pair of autosomes (AA, Aa or aa). This autosomal theory predicts eight different sex ratios $(1: 0 ; 3: 1 ; 5: 3$; $1: 1 ; 7: 9 ; 3: 5 ; 1: 3 ; 0: 1)$. Three of them $(5: 3$; $7: 9 ; 3: 5)$, that were obtained by Chen (1969) and Jalabert et al. (1971), were not predicted by the four sex chromosomes model (W, X, Y, Z). Application of the autosomal theory to the results obtained in Florida red tilapia showed noteworthy differences (Table 4). First, monosex male or female ratios have never been observed in Florida red tilapia whereas the expected frequencies of these sex-ratios should be respectively $17.5 \%$ and $10.0 \%$ according to the autosomal theory. Second, the observed percentage of crosses giving the sex-ratios of $5: 3 ; 7: 9$ and $3: 5$ is higher in Florida Red tilapia than expected according to the above theory. In contrast, the balanced sex-ratio $(1: 1)$ is theoretically expected more frequently than was actually observed in Florida red tilapia. Finally, the sex-ratios observed in Florida red tilapia were less scattered than those expected under the autosomal theory proposed by Avtalion and Hammerman (1978). Data from the Florida red tilapia suggest that sex ratios cannot be predicted by a simple monofactorial model and by the autosomal theory proposed by Avtalion and Hammerman (1978). The successive programmes of improvement of colour, growth rate and resistance to low temperature applied since the 1970s to the Florida red tilapia (Behrends and Smitherman, 1984), may have selected certain genotypes and thus contributed to the discrepancies between observed results and those predicted by the autosomal theory. The hypothesis of a differential mortality of certain genotypes, suggested by Jalabert et al. (1971) and Chen (1969), cannot be excluded. Moreover, as demonstrated by Shirak et al. (2002) in an inbred

Table 4

Number and percentage of crosses giving each sex-ratio $(\delta:$ : $)$ in theory of Avtalion and Hammerman (1978) and observed in Florida red tilapia (present study)

\begin{tabular}{|c|c|c|c|c|c|c|c|c|}
\hline Sex-ratio $(\hat{0}:+9)$ & $1: 0$ & $3: 1$ & $5: 3$ & $1: 1$ & $7: 9$ & $3: 5$ & $1: 3$ & $0: 1$ \\
\hline$\%$ males & 100 & 75 & 62.5 & 50 & 43.8 & 37.5 & 25 & 0 \\
\hline \multicolumn{9}{|l|}{ Avtalion and Hammerman's theory } \\
\hline No. of crosses giving the sex-ratio & 14 & 11 & 2 & 33 & 1 & 4 & 7 & 8 \\
\hline$\%$ of crosses giving the sex-ratio & 17.5 & 13.75 & 2.5 & 41.25 & 1.25 & 5 & 8.75 & 10 \\
\hline \multicolumn{9}{|l|}{ Results in Florida red tilapia } \\
\hline No. of crosses giving the sex-ratio & 0 & 11 & 27 & 32 & 12 & 14 & 11 & 0 \\
\hline$\%$ of crosses giving the sex-ratio & 0 & 10.3 & 25.2 & 29.9 & 11.2 & 13.1 & 10.3 & 0 \\
\hline
\end{tabular}


line of tilapia $O$. aureus, deleterious alleles could induce a sex selective mortality and could distort the sex-ratios. Not all sex determining factors originating from the four initial species are unlikely to have been conserved, this perhaps also explaining the difference with the autosomal theory. Globally, the results in Florida red tilapia, suggesting a polygenic sex determination model, show that a balanced sex ratio is maintained $(51.3 \%$ of males in all crosses Table 1) even in a population derived from a complex hybrid of unknown origin.

Production of genetically monosex population is well developed in $O$. aureus and O. niloticus (Mair et al., 1997; Desprez et al., 2003a). These recent studies have demonstrated that male genetic sex determining factors (sex chromosomes, autosomal factors) can be fixed in a line of breeders. Owing to the stability of sex ratio in most repeated crosses of single pair mating and the observation of skewed sex-ratio towards male in some progeny groups of Florida red tilapia, the selection of pairs with high percentages of male progeny may bring about a high proportion of male in their progenies. This process may be repeated in successive generations to progressively increase the male percentage. Of course, in a complex hybrid as Florida red tilapia, there should be much more potential for altering sex ratios through selective breeding than in $O$. niloticus and $O$. aureus. It is clear that developing this method to increase the male percentage in progenies of Florida red tilapia will be long and laborious, since their colour must be also conserved, but it may well be an alternative to using the hormonal sex inversion method to produce a population with high male percentage.

\section{Acknowledgements}

This research was supported by funds from Aquaculture Development Programme in Reunion Island (EEC/IFOP/DOCUP 1994-1999; 2000-2006; Conseil Régional de La Réunion, France). The authors wish to thank P. Valade (ARDA) for his help on the Bhattacharya test. The authors acknowledge P. Banaix and S. Jugand for reviewing the English version of the article. The authors gratefully thank Prof. G. Hulata and the anonymous referees for their comments and suggestions that have improved the quality of manuscript.

\section{References}

Avtalion, R.R., Hammerman, I.S., 1978. Sex determination in Sarotherodon (Tilapia). I. Introduction to a theory of autosomal influence. Bamidgeh 30, 110-115.

Baroiller, J.F., D'Cotta, H., 2001. Environment and sex determination in farmed fish. Comp. Biochem. Physiol. 130, 399-409.

Baroiller, J.F., Chourrout, D., Fostier, A., Jalabert, B., 1995. Temperature and sex chromosomes govern sex-ratios of the mouthbrooding cichlid fish Oreochromis niloticus. J. Exp. Zool. 273, 216-223.

Behrends, L.L., Smitherman, R.O., 1984. Development of cold tolerance population of red tilapia through introgressive hybridization. J. World Maric. Soc. 15, 172-178.

Behrends, L.L., Nelson, R.G., Smitherman, R.O., Stone, N.M., 1982. Breeding and culture of the red gold colour phase of tilapia. J. World Maric. Soc. 13, 210-220.

Bhattacharya, G.G., 1967. A simple method of resolution of a distribution into Gaussian components. Biometrics 23, $115-135$.

Chen, F.Y., 1969. Preliminary studies on the sex determining mechanism of Tilapia mossambica Peters and T. hornorum Trewavas. Verh. Internat. Verein. Limnol. 17, 719-724.

Desprez, D., Mélard, C., Hoareau, M.C., Bellemène, Y., Bosc, P., Baroiller, J.F., 2003a. Inheritance of sex in two ZZ pseudofemales lines of tilapia Oreochromis aureus. Aquaculture 218, $131-140$.

Desprez, D., Géraz, E., Hoareau, M.C., Mélard, C., Bosc, P., Baroiller, J.F., 2003b. Production of high percentage of male offspring with natural androgen, $11 \beta$ hydroxyandrostenedione (11ßOHA4), in Florida red tilapia. Aquaculture 216, 55-65.

Guerrero, R.D., Guerrero, L.A., 1988. Feasibility of commercial production of sex reversed Nile tilapia fingerlings in the Philippines. In: Pullin, R.S.V., Bhukaswan, T., Tonguthai, K., Maclean, J.L. (Eds.), Proceedings of the Second International Symposium on Tilapia in Aquaculture 16-20 March 1987, Bangkok, ThailandICLARM Conf. Proc., vol. 15, pp. 183-186.

Guerrero, R.D., Shelton, W.L., 1974. An aceto-carmine squash method for sexing juvenile fishes. Prog. Fish-Cult. 36, 56.

Jalabert, B., Kammacher, P., Lessent, P., 1971. Déterminisme du sexe chez les hybrides entre Tilapia macrochir et Tilapia nilotica. Etude de la sexe-ratio dans les recroisements des hybrides de première génération par les espèces parentes. Ann. Biol. Anim. Biochim. Biophys. 11 (1), 155-165 (In French with English abstract).

Mair, G.C., Scott, A.G., Penman, D.J., Skibinski, D.O.F., Beardmore, J.A., 1991a. Sex determination in the genus Oreochromis. 1. Sex reversal, gynogenesis and triploidy in $O$. niloticus (L). Theor. Appl. Genet. 82, 144-152.

Mair, G.C., Scott, A.G., Penman, D.J., Skibinski, D.O.F., Beardmore, J.A., 1991b. Sex determination in the genus Oreochromis. 
2. Sex reversal, hybridisation, gynogenesis and triploidy in $O$. aureus Steindachner. Theor. Appl. Genet. 82, 153-160.

Mair, G.C., Abucay, J.S., Skibinski, D.O.F., Beardmore, J.A., 1997.

Genetic manipulation of sex ratio for the large scale production of all-male tilapia, Oreochromis niloticus. Can. J. Fish. Aquat. Sci. 54, 396-404.

Majumdar, K.C., McAndrew, B.J., 1983. Sex ratio from interspecific crosses within the tilapias. In: Fishelson, L., Yaron, Z. (Eds.), Proceedings of the First International Symposium on Tilapia in Aquaculture. Tel Aviv University, Tel Aviv, pp. $261-269$.

Müller-Belecke, A., Hörstgen-Schwark, G., 1995. Sex determination in tilapia (Oreochromis niloticus) sex ratios in homozygous gynogenetic progeny and their offspring. Aquaculture 137, $57-65$.
Pruginin, Y., Rothbard, S., Wohlfarth, G.W., Halevy, A., Moav, R., Hulata, G., 1975. All- male broods of Tilapia nilotica $\times$ T. aurea hybrids. Aquaculture 6, 11-21.

Trombka, D., Avtalion, R.R., 1993. Sex determination in tilapia - a review. Isr. J. Aquac.-Bamidgeh 45, 26-37.

Shirak, A., Palti, Y., Cnaani, A., Koroi, A., Hulata, G., Ron, M., Avtalion, R.R., 2002. Association between loci with deleterious alleles and distorted sex ratios in an inbred line of tilapia (Oreochromis aureus). J. Heredity 93, 270-276.

Wohlfarth, G.W., 1994. The unexploited potential of tilapia hybrids in aquaculture. Aquac. Fish. Manage. 25, 781-788.

Wohlfarth, G.W., Wedekind, H., 1991. The heredity of sex determination in tilapias. Aquaculture 92, 143-156. 